Burdick, D. (1961). Surg. Gynec. Obstet., 112, 334.

Campiche, P., and Lazarus-Barlow, W. S. (1905). Arch. Middlx Hosp., 5, 83.

Coupland, S. (1902). "The Cancer Charity of the Middlesex Hospital, 1792-1902, in Reports from the Cancer Research Laboratories: The Middlesex Hospital, vol. 1, edited by A. G. R. Foulerton. Macmillan, London.

Daland, E. M. (1927). Surg. Gynec. Obstet., 44, 264.

Eggers, C., de Cholnoky, T., and Jessup, D. S. D. (1941). Ann. Surg., 113, 321.

Everson, T. C., and Cole, W. H. (1956). Ibid., 144, 366.

Forber, J. E. (1931). Rep. publ. Hlth med. Subj., No. 66. H.M.S.O., London.

Greenhough, R. B. (1925). J. Cancer Res., 9, 453.

Greenwood, M. (1926). Rep. publ. Hlth med. Subj., No. 33. H.M.S.O., London.

Haagensen, C. D. (1956). Diseases of the Breast. Saunders, Philadelphia.

Harrington, S. W. (1952). J. Amer. med. Ass., 148, 1007.

Kaae, S., and Johansen, H. (1962). Amer. J. Roentgenol., 87, 82. Lazarus-Barlow, W. S., and Leeming, J. H. (1924). Brit. med. J., 2. 266 .
Ledoux-Lebard (1906). Quoted by C. D. Haagensen, Amer. J. Cancer, 1933, 18, 42 .

Lewis, D., and Rienhoff, W. F. (1932). Ann. Surg., 95, 336

McKinnon, N. E. (1951a). Canad. J. publ. Hlth, 42, 218 (1951b). Ibid., 42, 88. (1954). Lancet, 1, 251

(1955). Canad. med. Ass., J., 73, 614.

Nathanson, I. T., and Welch, C. E. (1936). Amer. J. Cancer, 28, 40 .

Park, W. W., and Lees, J. C. (1951). Surg. Gynec. Obstet., 93, 129.

Paterson, R. (1948). Treatment of Malignant Disease by Radium and $X$-rays, p. 309. Arnold, London

Richards, G. E. (1948). Brit. J. Radiol., 21, 109.

Robbins, G. F., Berg, J. W., Bross, I., de Padua, C., and Sarmiento, A P. (1959). Cancer, 12, 688.

Shimkin, M. B. (195i). Ibid., 4, 1.

Smithers, D. W., Rigby-Jones. P., Galton, D. A. G., and Payne, P. M. (1952). Brit. J. Radiol., Suppl. No. 4.

Wade, P. (1946). Brit. J. Radiol., 19, 272.

Wilson, E. (1845). The History of the Middlesex Hospital, pp. 129, 133. Churchill, London.

\title{
TREATMENT OF RHEUMATIC FEVER WITH 12-WEEK COURSES OF CORTISONE OR SALICYLATE
}

E. G. L. BYWATERS, M.B., F.R.C.P. Rheumatism Research Unit, M.R.C., Canadian

The relative values of salicylate or steroid (in conjunction with bed rest and penicillin therapy) in rheumatic fever continue to be controversial. Thus Massell et al. (1961) found that, on the whole, patients treated with hormone subsequently did better than those given salicylate or no specific antirheumatic therapy as regards the disappearance of significant murmurs, yet Friedman et al. (1962) found no beneficial effect.

We have previously published our findings on the course of rheumatic fever in hospital in two series of cases-one treated by bed rest and the other by six-week courses of A.C.T.H., cortisone, or salicylate in the U.K.-U.S. Co-operative Trial (Bywaters and Thomas, 1961 ; U.K.-U.S. Trial, 1955). We concluded that most cases of rheumatic fever responded to bed rest alone and that, though salicylates bring about symptomatic relief, they do not significantly alter the course of the disease or have any effect on cardiac status. Steroids had no demonstrable beneficial effect on the heart in most cases except possibly in the disappearance of soft diastolic murmurs, and this was shown in a later paper to have little effect on the findings five years later (Thomas, 1961). They were, however, indicated in cases with cardiac enlargement and activity, for by suppressing the rheumatic activity they diminished the risk of failure. Also, they were useful in patients with established failure and activity; for after the activity had been controlled the failure responded to drugs such as digitalis and mersalyl. The conclusion of the analysis of all cases treated in the Co-operative Trial at the end of one and five years was that cortisone and A.C.T.H. had no advantage over salicylate, and we found little difference in end-results between our cases treated by bed rest and those treated in this trial.

A criticism of the treatment in the Co-operative Trial has been that the six-week courses were too short, and that had longer ones been used steroid might have been proved more effective than salicylates. With this in mind we have treated a third series of cases, half of them with 12-week courses of cortisone and the other half with similar courses of salicylates. We now describe changes in cardiac status that occurred in hospital in

\section{G. T. THOMAS, M.B., M.R.C.P.}

Red Cross Memorial Hospital, Taplow, Bucks

these cases and compare them with those treated in the Co-operative Trial, and later consider the findings at five-year follow-up in the two groups.

\section{Third Series, Treated with 12-week Courses of Cortisone or Salicylate}

The series comprised 49 patients aged 16 years or less who fulfilled the criteria for diagnosis of rheumatic fever as defined by Duckett Jones, as did those in the U.K.-U.S. trial. All 49 had been admitted within 14 days of onset of their first attacks. Twenty-four patients (determined "blindly") received $300 \mathrm{mg}$. of cortisone by mouth daily for two days, $200 \mathrm{mg}$. for five days, $100 \mathrm{mg}$. for six weeks, and then by weekly reductions to $25 \mathrm{mg}$. in the last and twelfth week. The other 25 were given salicylates on a body-weight basis in the form of calcium aspirin. All were given penicillin prophylaxis in hospital (benzylpenicillin 200,000 units b.d. or phenoxymethylpenicillin $125 \mathrm{mg}$. b.d.), and most of them continued to take the tablets as advised after discharge.

Cardiac status on admission and any changes that occurred during the stay in hospital are shown in Table I. Also included in the table are 60 patients seen in first attacks out of a total of 86 of our own

Table I.-Cardiac Status in Hospital: 49 Cases in Third Series and 60 in U.K.-U.S. Trial

\begin{tabular}{|c|c|c|c|c|}
\hline & \multirow{2}{*}{$\begin{array}{c}\text { No. } \\
\text { of } \\
\text { Cases }\end{array}$} & \multirow{2}{*}{$\begin{array}{c}\text { No. } \\
\text { Developing } \\
\text { Murmurs }\end{array}$} & \multicolumn{2}{|c|}{ Grade of Murmurs } \\
\hline & & & $1-2$ & 3 \\
\hline $\begin{array}{l}\text { No carditis on admission: } \\
\text { Third series } \\
\text { U.K.-U.S. triai } \\
\text { Admission } 0-14 \text { days } . . \\
., \quad 14+\text { days .. } \\
\end{array}$ & $\begin{array}{l}19 \\
13\end{array}$ & $\begin{array}{l}6 \\
2\end{array}$ & $\begin{array}{l}5 \\
2\end{array}$ & $\begin{array}{l}1 \\
0\end{array}$ \\
\hline Total & 32 & 8 & 7 & 1 \\
\hline & & $\begin{array}{l}\text { No. Losing } \\
\text { Murmurs }\end{array}$ & & \\
\hline $\begin{array}{c}\text { Carditis on admission: } \\
\text { Third series } \\
\text { U.K.-U.S. trial } \\
\text { Admission } 0-14 \text { days } \\
,, \quad 14+ \\
\quad, \quad, \ldots\end{array}$ & $\begin{array}{ll}30 & \\
47 & 13 \\
& 34\end{array}$ & $\begin{array}{rr}16 & \\
18 & 7 \\
& 11\end{array}$ & $\begin{array}{rr}16 & \\
17 & 7 \\
& 10\end{array}$ & $\begin{array}{l}0 \\
1\end{array}$ \\
\hline Total .. & 77 & 34 & 33 & 1 \\
\hline
\end{tabular}


cases treated in the U.K.-U.S. trial. Twenty of these 60 had, like those in the third series, been admitted within 14 days, the other 40 after 14 days. Out of the total of 109 cases (49 in the third series and 60 in the U.K.), 32 had no carditis on admission. Eight of these 32 developed murmurs in hospital; 6 out of the 19 in the third series and 2 out of the 13 in the U.K. series (the 2 in the U.K. series were among 7 cases admitted within 14 days). Thus similar numbers in the third series developed murmurs as in the U.K. series, and of those that did develop murmurs equal numbers had been on salicylate and cortisone. The other 77 cases (30 in the third series and 47 in the U.K. series) had carditis on admission. In 34 of them murmurs disappeared in hospital ; in 16 out of 30 in the third series and in 18 out of 47 in the U.K. ( 7 in the U.K. were among 13 recently admitted cases). Thus similar numbers in both series lost murmurs, and of the 16 cases in the third series in which murmurs disappeared seven had been on cortisone and nine on salicylate.

Thus longer courses of treatment used in this third series had no advantage over the shorter ones used in the Co-operative Trial, as similar numbers of cases without carditis on admission developed murmurs and of those with carditis lost murmurs in both. In the third series cortisone had no advantage over salicylate: murmurs developed and disappeared with equal frequency in the two treatment groups.

\section{Five-year Follow-up}

Of the 49 cases in the third series, three defaulted during the follow-up period of five years, as did 6 out of the 60 with first attacks in the U.K.-U.S. trial. Thus 46 in the third series and 54 in the U.K. trial were seen at five years, during which time two in the third series and three in the trial had recurrences. The follow-up findings at five years are considered first in those that did not have recurrences- 44 in the third series and 51 in the trial (Table II). Similar proportions in both

TABLE II.-Five-year Follow-up: 95 Patients without Recurrences, 44 in the Third Series and 51 in U.K.-U.S. Trial

\begin{tabular}{|c|c|c|c|c|c|}
\hline & & \multirow{2}{*}{$\begin{array}{l}\text { No. } \\
\text { of } \\
\text { Cases }\end{array}$} & \multicolumn{3}{|c|}{ Status at Follow-up } \\
\hline & & & Normal & No Change & Worse \\
\hline $\begin{array}{l}\text { No carditis in hospita } \\
\text { Third series } \\
\text { U.K.-U.S. trial } \ldots\end{array}$ & 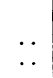 & $\begin{array}{r}11 \\
8\end{array}$ & $\begin{array}{r}11 \\
8\end{array}$ & $\begin{array}{l}0 \\
0\end{array}$ & $\begin{array}{l}0 \\
0\end{array}$ \\
\hline Total & $\ldots$ & 19 & 19 & 0 & 0 \\
\hline $\begin{array}{l}\text { Grade } 1-2 \text { murmurs } \\
\text { pital: } \\
\text { Third series } \\
\text { U.K.-U.S. trial }\end{array}$ & $\begin{array}{c}\text { hos- } \\
\ldots \\
\cdots \\
\end{array}$ & $\begin{array}{l}30 \\
30\end{array}$ & $\begin{array}{l}22 \\
23\end{array}$ & $\begin{array}{l}8 \\
7\end{array}$ & $\begin{array}{l}0 \\
0\end{array}$ \\
\hline Total & $\cdots$ & 60 & 45 & 15 & 0 \\
\hline $\begin{array}{c}\text { Grade } 3 \text { murmurs } \\
\text { pital: } \\
\text { Third series } \\
\text { U.K.-U.S. trial }\end{array}$ & $\begin{array}{c}\text { hos- } \\
\ldots \\
\ldots\end{array}$ & $\begin{array}{r}3 \\
13\end{array}$ & $\begin{array}{l}1 \\
1\end{array}$ & $\begin{array}{r}1 \\
10\end{array}$ & $1^{*}$ \\
\hline Total & $\ldots$ & 16 & 2 & 11 & 3 \\
\hline
\end{tabular}

groups had had no or minimal carditis (grade 1-2 murmurs) in hospital, but there was a preponderance of cases in the Co-operative Trial with more marked carditis (grade 3 murmurs). At five years all cases in both series with no carditis in hospital were normal. Of 60 with minimal carditis ( 30 in the Co-operative Trial and 30 in the third series), similar numbers in both series had residual heart disease at five years; seven of the eight with slight residual carditis in the third series had been on cortisone. There were too few cases in the third series with marked carditis to make any comparison between the two groups possible, but one case treated with salicylates in the third series died, while none in the Co-operative Trial died, though 2 out of 13 became worse.

Thus at five years prolonged courses of cortisone or salicylate as used in the third series had no demonstrable advantage over the shorter ones in the Co-operative Trial, and cortisone had none over salicylate. In a previous paper we showed that in patients who did not have recurrences there was no difference at five-year follow-up between those who had been treated by bed rest only and others treated in the U.K.-U.S. trial (Thomas, 1961). Without recurrences, therefore, we have found no significant difference at five-year follow-up between patients treated by bed rest alone, those given six-week courses of A.C.T.H., cortisone, or salicylate in the U.K. trial, and others treated with 12-week courses of cortisone or salicylate in the third series.

\section{Recurrences}

Two of the 46 in the third series who were seen at five years had recurrences during this period, as did 3 out of 54 in the U.K. trial. Thus the recurrence rate in the two series, both of which had been on prophylaxis (sulphonamides in the U.K. trial and penicillin in the third series) was low-4\% (2 out of 46 ) in the third and $5.5 \%$ (3 out of 54 ) in the U.K. trial. No case in either series had more than one recurrence and none was worse after them. In the bed-rest series who were not given prophylaxis, on the other hand, recurrences were more common-in 9 out of 107 admitted in first attacks $(8.4 \%)$-there was sometimes more than one recurrence and two of the nine patients with recurrences were worse after them.

Thus the only difference at five-year follow-up between these three series of cases was that the recurrence rate had been higher in the bed-rest, nonprotected group than in the other two, and some cases in this group who had recurrences were worse after them whereas there was no deterioration after recurrences in the other two: without recurrences there was no difference between the three groups. Thus the cardiac status at five years did not appear to be influenced by treatment in hospital with cortisone or salicylate even in the higher dosage used in the third series, but it did appear to be improved in those cases where prophylaxis had been used.

\section{Discussion}

While this disease is on the wane in regard to both incidence and severity in the more prosperous countries, it is still a major problem in many parts of the world and particularly in crowded areas with a low standard of living. A major advance has been made in the field of prevention both of first attacks and of recurrent attacks. Modern treatment does not seem otherwise to be greatly in advance of that which was known to our fathers, except possibly in severe cases with carditis and heart failure. Here it seems likely that some amelioration is feasible, but because of the rarity of such cases in countries such as this it is difficult to prove on a controlled basis. As has been previously stated, "the major factor in determining the incidence of rheumatic heart disease at the end of five years is the status of the heart at the time treatment was begun" (U.K.-U.S. Co-operative Trial). 


\section{Summary}

A series of patients with rheumatic fever have been treated, half with 12-week courses of cortisone and half with aspirin.

No difference was noted between the two treatment groups in the development or disappearance of significant murmurs during the stay in hospital, nor was there any difference between them at five-year follow-up.

The series has been compared with another comprising similar cases that were treated with six-week courses of A.C.T.H., cortisone, or aspirin in the U.K.-U.S. Co-operative Clinical Trial. No difference was apparent between them either in hospital or at five-year follow-up.

Thus prolonged (12 weeks) courses of cortisone or aspirin as used in the present series had no advantage over the shorter one used in the Co-operative Clinical Trial and cortisone had none over salicylate.

Excluding patients with recurrences during the fiveyear follow-up period, those who had been treated here with bed rest and given no specific antirheumatic treatment or prophylaxis did as well during this five-year period as those in the Co-operative Trial and the recent series who were on prophylaxis. However, with recurrences the bed-rest non-protected group fared less well ; recurrences were more common and many were worse after them.

Prophylaxis is still, therefore, the most effective way we have of reducing the severity of residual heart disease, and there is as yet no evidence that steroid is of value in this regard.

\section{REFERENCES}

Bywaters, E. G. L., and Thomas, G. T. (1961). Brit. med. J., 1, 1628.

Friedman, S., Harris, T. N., and Caddell, J. L. (1962). J. Paediat., $60,55$.

Massell, B. J., Czoniczer, G., Jhaveri, S., Barnet, R., and Polansky, B. J. (1961). Inflammation and Diseases of Connective Tissue, edited by L. C. Mills and J. H. Moyer. Saunders, Philadelphia.

Thomas, G. T. (1961). Brit. med. J., 1, 1635.

U.K.-U.S. Co-operative Clinical Trial of A.C.T.H., Cortisone, and Aspirn (1955). Ibid., 1, 555. (1960). Ibid., 2, 1033 .

\footnotetext{
“The [Royal College of] Physicians' report on the relationship between smoking and lung cancer has had an appreciably greater initial impact on tobacco consumption than was generally supposed. Several weeks after the report was released it was widely estimated that cigarette sales had fallen by about 10 per cent. But withdrawals of tobacco from bond for home consumption (which to all intents and purposes are the same as sales to the public in normal times) fell by over 18 per cent in April, the first full month after the report was issued. The precise figures were $17,122,000 \mathrm{lb}$. in April this year compared with $21,155,000 \mathrm{lb}$. in April, 1961. Prior to the report, withdrawals were only slightly less than those for a year earlier. Thus it is fair to assume that virtually all of the April drop was directly attributable to the Physicians' report and the publicity it received, though part of it may have reflected a runnning down of stocks on retailers' shelves. Recent statements from the trade indicate that the public has already recovered from the shock. Estimates now suggest that cigarette consumption is now no more than 5 per cent. below last year's levels and may be almost back to them. Thus if this is true the pattern of demand has been similar to that which usually follows an increase in tobacco duty." (The Times, July 6.)
}

\section{RHEUMATIC FEVER IN ADOLESCENTS AND ADULTS}

BY

THOMAS B. BEGG, M.B., F.R.F.P.S., M.R.C.P. J. W. KERR, M.B., F.R.F.P.S., M.R.C.P. AND

\author{
B. R. KNOWLES, M.B., M.R.C.P.Ed.
}

Clinical Chemotherapy Research Unit of the Medical Research Council, Western Infirmary, Glasgow

In recent years there has been a decline in the incidence of rheumatic fever (Brit. med. J., 1959), and this fall has been accentuated since antibiotics became generally available for the treatment of throat infections. There is also an impression that the illness is less severe now than it was in the past and that the immediate mortality is less (Royal College of Physicians, 1957).

Some recent studies of rheumatic fever have been concerned with children (Massell, 1958 ; Co-operative Clinical Trial, 1960 ; Bywaters and Thomas, 1961) or predominantly with young males in the British or American armed Forces (Slater and Rosenbaum, 1959 ; Malpas and Landon, 1960 ; Gray, 1949; Carmichael, 1956 ; Bates, 1958).

The present paper reports on the incidence, clinical picture, and response to treatment of rheumatic fever in adolescents and adults admitted in the past seven years to this unit.

\section{Clinical Material and Investigations}

During the period between March, 1954, and February, 1961,139 patients over 12 years of age satisfied the diagnostic criteria for acute rheumatic fever. These were essentially those of Jones (1944) as amended by the M.R.C. and the American Heart Association for their Co-operative Clinical Trial (1955); four further minor modifications were made to the criteria, and their final form is given below.* Most of the patients were referred as emergency admissions by their family doctor and the remainder were transferred to this unit from other wards in the hospital.

*The criteria are divided into major and minor criteria. One major and two minor or two major and one minor criteria are demanded to substantiate a diagnosis of acute rheumatism.

\section{Major Criteria}

1. Carditis.-Any one of the following: (a) development of an organic apical systolic murmur, or an aortic or apical diastolic murmur; $(b)$ change of heart size greater than $15 \%$ by standard radiological methods; $(c)$ a pericardial rub or effusion ; $(d)$ congestive cardiac failure in a patient under 25 years, in the absence of other causes, shown by two or more of the following: (i) dyspnoea or orthopnoea, (ii) hepatomegaly, (iii) basal rales, (iv) elevated jugular venous pressure, (v) oedema.

2. Polyarthritis. - Pain and either limited active movement or tenderness in two or more joints.

3. Chorea, with movements of at least moderate severity.

4. Subcutaneous nodules.

5. Erythema marginatum or annulare.

Minor Criteria

1. Fever.-Over $99.3^{\circ} \mathrm{F}$. $\left(37.4^{\circ} \mathrm{C}\right)$ orally or over $100.3^{\circ} \mathrm{F}$. $\left(38^{\circ} \mathrm{C}\right.$ ) rectally at least twice in $24^{\circ}$ hours, or over $100.3^{\circ} \mathrm{F}$. $\left(38^{\circ} \mathrm{C}\right.$.) orally or over $101.3^{\circ} \mathrm{F} .\left(38.5^{\circ} \mathrm{C}\right.$.) rectally, recorded once. 2. E.S.R. not less than $15 \mathrm{~mm}$. in one hour (Westergren).

3 . Evidence of previous streptococcal infection: $(a)$ culture with significant number of $\beta$-haemolytic streptococci, or $(b)$ antistreptolysin $\mathrm{O}$ titre of at least 200 units per $\mathrm{ml}$., or $(c)$ a reliable history of a sore throat and fever in the four weeks before the onset of rheumatic symptoms.

4. P-R interval of 0.2 second or more.

5. A reliable history of rheumatic fever, as defined in these criteria, or evidence of pre-existing rheumatic heart diseasenamely, an organic apical systolic murmur or an apical or basal diastolic murmur. 